\title{
Kekerasan Verbal dalam cerpen Jagal karya Dorothea Rosa Herliany
}

\author{
Alexander Bala \\ Program Studi Pendidikan Bahasa dan Sastra Indonesia, \\ Universitas Flores \\ Pos-el: naradiring@gmail.com
}

\begin{abstract}
Verbal abuse has become a logical consequence of communication events in social interactions. This research examines verbal violence in the short story of Dorothea Rosa Herliany's Jagal. The research method used is the literature method with a qualitative descriptive approach. The theory used is the theory of verbal violence. The results of this study indicate that verbal violence in the short story Jagal by Dorothea Rosa Herliany occurs between the main character Karto and the local community in the form of phrases and sentences.
\end{abstract}

Keywords: language, short stories, verbal violence.

\section{Abstrak}

Kekerasan verbal telah menjadi konsekuensi logis dari peristiwa komunikasi dalam interaksi sosial. Penelitian ini menelaah tentang kekerasan verbal dalam cerpen Jagal karya Dorothea Rosa Herliany. Metode penelitian yang digunakan adalah metode kepustakaan dengan pendekatan deskriptif kualitatif. Teori yang digunakan adalah teori kekerasan verbal. Hasil penelitian ini menunjukkan bahwa kekerasan verbal dalam cerpen Jagal karya Dorothea Rosa Herliany terjadi pada tokoh utama Karto dengan masyarakat setempat yang berwujud frase dan kalimat.

Kata kunci: bahasa, cerpen, kekerasan verbal.

\section{PENDAHULUAN}

Dalam kehidupan bermasyarakat, kekerasan merupakan suatu perbuatan yang dikutuk oleh banyak orang. Apalagi secara hukum tindakan kekerasan mengarah kepada perbuatanperbuatan yang mengerikan, menakutkan, menyakitkan, atau bahkan mematikan. Siapapun yang melakukan kekerasan terhadap orang lain harus dituntut secara hukum.

Ada banyak kisah atau fenomena kekerasan yang terjadi di sekeliling kita. Entah itu kekerasan fisik, maupun kekerasan verbal atau kata-kata. Kekerasan yang demikian terjadi hampir pada setiap aspek kehidupan sosial kita, baik politik, budaya, agama, bahkan pendidikan. Misalnya, kekerasan yang terjadi dalam kehidupan rumah tangga antara suami dan istri, sampai pada penyelesaian berbagai masalah di tingkat bangsa pun, orang masih menggunakan jalan kekerasan. Konflik pilkada, sidang di DPR, kegiatan orientasi siswa atau mahasiswa yang diadakan di awal tahun akademik, menegakkan disiplin di sekolah (atau 
institusi lain), banyak menggunakan kekerasan. Fenomene-fenomena ini menunjukkan bahwa masalah kekerasan yang terjadi di sekitar kita merupakan masalah yang sangat serius.

Kekerasan diartikan sebagai suatu tindakan yang tidak menyenangkan atau merugikan orang lain, baik secara fisik maupun psikis. Kekerasan tidak hanya berbentuk eksploitasi fisik semata, tetapi juga kekerasan psikis. Kekerasan psikislah yang perlu diwaspadai karena akan menimbulkan efek traumatis yang cukup lama bagi si korban. Dewasa ini, tindakan kekerasan dalam pendidikan sering dikenal dengan istilah bullying. Apalagi dengan bertumbuhnya media-media online yang begitu dahsyat, fenomena kekerasan atau bullying sangat mudah ditemukan di dinding-dinding platform media sosial. Cacian, makian, hujatan, dan kata-kata kasar menjadi menu bagi pengguna media sosial.

Artikel ini akan membahas secara khusus tentang kekerasan verbal yang terdapat dalam cerpen Jagal karya Dorothea Rosa Herliany. Sebagai contoh, berikut dikemukakan satu contoh data kekerasan verbal yang terdapat dalam cerpen Jagal, karya Dorothea Rosa Herliany.

Tangan kanan membawa golok yang masih dibasahi darah (Jagal, p.25, hlmn.28).

Data yang tercetak tebal di atas, golok yang masih dibasahi darah, menunjukkan bahwa ada sebilah golok atau parang yang baru saja digunakan untuk menggorok leher seorang yang bernama Warsinah. Golok tersebut masih penuh darah, dan mengalir memenuhi mata golok yang sedang dipegang oleh Karto. Bagi siapa saja yang melihat langsung golok yang masih dibasahi darah pasti akan merasa ngeri dan menakutkan. Mungkin orang tersebut akan lari dan bersembunyi. Pada saat itu, sesungguhnya golok yang masih dibasahi darah dipandang sebagai suatu kekerasan verbal. Dari golok yang masih dibasahi darah tersebut hendak menyatakan kepada orang lain bahwa segera meninggalkan tempat itu, atau jangan "macam-macam" kalau tidak maka orang itu akan menjadi korban berikutnya.

Bentuk kekerasan seperti contoh data di atas dikategorikan sebagai kekerasan verbal, di samping kekerasan fisik dan kekerasan psikologis. Bentuk kekerasan ini hampir tidak pernah menjadi pokok perhatian berbagai pihak, pada hal jika diamati, bentuk kekerasan inilah yang memberikan dampak yang cukup besar, terutama dampak bagi masyarakat secara makro. Tampak dalam kehidupan kita sehari-hari secara nyata adalah kekerasan fisik dan kekerasan psikologis. Kekerasan verbal merupakan sebuah kekerasan yang mudah dilihat 
wujudnya, namun sebenarnya bentuk kekerasan ini sangat mudah diamati dan hampir dialami oleh semua orang dalam kehidupannya sehari-hari.

Kekerasan adalah perihal keras, yakni perbuatan yang menyebabkan cedera atau matinya orang lain atau menyebabkan kerusakan fisik atau lambang orang lain. Menurut Gultung (dalam Windhu,1192: 64-79), selain yang bersifat fisik, kerasan lebih banyak ditentukan oleh segi akibat pengaruh sesuatu perbuatan atau keadaan pada kekerasan. Gultung mengemukakan enam aspek pembedaan kekerasan fisik dan psikologis, pengaruh positif dan negatif, kekerasan atau tidak tampak atau tersembunyi.

Bentuk-bentuk tindak kekerasan yaitu sebagai berikut. Emosional diartikan dengan menyentuh perasaan, mengharukan, dengan emosi, beremosi atau penuh emosi. Emosi didefinisikan sebagai perasaan yang berkembang dan surut dalam waktu singkat atau keadaan dan reaksi psikologi dan fisiologis seperti kegembiraan, kesedihan, keharuman, kecintaan (Moeliono,1988:228). Kekerasan fisik biasa selalu diawali dengan kekerasan emosional seperti mengancam ataupun memaksa korban untuk melakukan apa yang mereka inginkan.

Baryadi (2003:1097) mengemukakan bahwa kekerasan verbal adalah bahasa yang mengandung muatan psikiologis yang biasanya menyerang orang lain dengan cara menghina, menyudutkan, mengancam, mengkritik, menyindir, melecehkan dan merendahkan.

Kekerasan verbal ini juga erat kaitannya dengan kekerasan emosional karena setiap kata yang diucapkan rasa marah, kesal, benci, dendam yang digolongkan sebagai kekerasan verbal apabila didukung oleh konteks kalimatnya juga latar tempat dimana kejadian tersebut berlangsung dan bagaimana situasi yang mendukung kejadian tersebut.

Kekerasan verbal bisa juga disampaikan tidak langsung, tetapi dampaknya bisa sangat menghina dan melecehkan mereka. Seringkali kita membungkus atau melampiaskan kekecewaan, ketidakpuasan dengan nada humor, guyonan atau canda. Jika mereka tersinggung dan kemudian memprotesnya, maka kita akan membela diri dengan berkata, " $A h$, kan cuman bercanda“. Semua orang maklum bahwa kadang-kadang kita merasa jengkel, kecewa, bahkan marah terhadap mereka, kalau mengikuti lirik, pasangan, saudara, anak, teman, bahkan orang tua juga manusia. Dimana mereka punya rasa dan punya hati untuk disayang dan dihargai. Tidak ada makhluk di dunia ini yang ingin dilukai perasaanya, baik dengan kekerasan fisik maupun verbal. Ucapan-ucapan bercanda menghina dan merendahkan itu akan terkenang dalam pita memori, sehingga makin lama makin bertambah dan dirasa beta sehingga akhirnya mereka memiliki negative dalam komunikasi. Ketika kita meyadari 
bahwa kekerasan verbal tersebut tersebut tidak ada gunanya, perbaiki sekarang, jangan tunda sampai besok. Jika kita menundahnya hingga esok hari, kemungkinan sudah terhambat.

Menurut Taum (1997:157) cerpen adalah kisahan pendek (kurang dari 10.000 kata) yang memberikan kesan tunggal yang dominan dan memusatkan dari pada satu tokoh dalam satu situasi. Rahman (1995: 91) mengatakan cerpen adalah suatu kebulatan ide yang mengemukakan masalah yang terbatas dan memberikan kesan tunggal kepada pembaca.

Ciri-ciri cerita pendek adalah (a) hanya mengungkapan satu masalah tunggal, artinya satu masalah atau topik saja yang diulas, (b) cerpen menunjukkan adanya kebulatan kisah atau cerita, artinya hanyalah konflik dari terpanjang, dan (c) dalam cerpen adanya pemusatan perhatian pada satu tokoh utama atau tokoh utama merupakan ide sentral dalam cerita (Rampan, 1995: 45).

Penelitian ini merupakan penelitian nonstatistik. Data yang dikumpulkan berupa kata-kata bukan angka. Penelitian seperti ini disebut penelitian kualitatif. Moleong mengatakan bahwa salah satu ciri dari metode penelitian kualitatif, yakni bersifat deskriptif. Tujuan dari metode ini adalah untuk membuat deskripsi faktual dan akurat mengenai faktafakta, sifat-sifat serta hubungan antarfenomena yang diselidiki, (1998: 63).

Data dalam penelitian ini berupa data tulis berwujud kata-kata, frase, kalimat-kalimat, serta penggalan paragraf yang mengandung kekerasan verbal yang diambil dari cerpen Jagal, karya Dorothea Rosa Herliany. Sumber data pada penelitian ini adalah cerpen Jagal, karya Dorothea Rosa Herliany yang terdapat dalam buku Aliran-Jenis Cerita Pendek yang ditulis oleh Korrie Layun Rampan. Buku ini diterbitkan oleh Penerbit Nusa Indah Ende, tahun Cerpen Jagal dalam buku ini terdapat pada halaman 26-28, dengan ISSBN 979-429-042-4.

Teknik pengumpulan data menggunakan teknik baca dan catat. Pencatatan dilakukan terhadap kalimat-kalimat atau penggalan paragraf yang merujuk pada kekerasan verbal yang terdapat dalam cerpen Jagal karya Dorothea Rosa Herliany. Analisis terhadap data dilakukan melalui model interaktif yang diketengahkan oleh Milles dan Huberman (2009).

\section{PEMBAHASAN}

Data hasil penelitian akan disajikan secara informal, artinya disajikan tanpa menggunakan angka, rumus, bagan, melainkan disajikan dalam bentuk verbal.

Setelah dua tahun menghilang kemunculan Karto kembali menyulut amarah penduduk desa pedukuhan Gading (Jagal, p.1, hlmn.26). 
Frase bercetak tebal menyulut amarah pada data di atas menunjukkan emosi penduduk desa pedukuhan Gading. Emosi yang terpendam akibat sesuatu perbuatan yang tidak menyenangkan. Perbuatan yang melanggar norma dalam kehidupan bermasyarakat. Emosi tersebut ibarat menyala api ketika melihat orang yang tidak menyenangkan itu dua tahun menghilang, muncul kembali di tengah-tengah penduduk desa. Kehadirannya menyulut amarah penduduk. Menyulut artinya mencucuh dengan puntung rokok (KBBI, 2008: 1390). Oleh karena itu, dalam kehidupan sehari-hari menyulut amarah sering diartikan sebagai membakar marah, membuat orang marah.

Di mata mereka, sosok Karto memang tak lebih dari virus mengerikan.

\section{Perampokan besar-besaran, pencurian, perkosaan, pembunuhan,} semuanya seperti terjadi tanpa halangan suatu apa di desa Gading. (Jagal, p.1, hlmn.26).

Karto dianggap atau dipandang oleh masyarakat desa pedukuhan Gading sebagai virus mengerikan. Virus artinya penyebab munculnya suatu penyakit. Karena dianggap penyakit, bahkan penyebab penyakit, maka Karto selalu dimusuhi dan tidak disukai oleh masyarakat setempat. Penyakit atau virus mengerikan dalam kalimat di atas berkenan dengan virus atau penyakit sosial, seperti perampokan, pencurian, perkosaan, dan pembunuhan. Dengan demikian, semua perampokan, pencurian, perkosaan, dan pembunuhan yang terjadi di desa pedukuhan Gading didalangi oleh Karto.

Ketika para warga mencari kambing hitam peristiwa kejahatan itu, segera mudah ditemukan ketika perilaku Karto cukup bagi dalil-dalil mereka (Jagal, p.1, hlmn.26).

Idiom kambing hitam pada data di atas menyamakan perilaku para penyebab masalah di desa Pedukuhan Gading seperti kambing. Dari semua dugaan masayarakat tentang para pelaku itu adalah Karto. Dilihat dari perilaku Karto dalam kehidupannya di masyarakat, meyakinkan bahwa Karto adalah dalang berbagai masalah sosial tersebut.

Siapa lagi kalau bukan dia? (Jagal, p.2, hlmn.26).

Siapa lagi kalau bukan dia? Kalimat ini memberikan penekanan atau penegasan dugaan masyarakat tentang siapa penyebab berbagai masalah sosial di desa Pedukuhan Gading selama ini. Artinya, Karto adalah satu-satunya penyebab. Penggunaan kata dia menunjuk pada tokoh Karto dalam cerpen ini. Seharusnya tuduhan masyarakat di desa Pedukuhan Gading kepada Karto didasarkan pada bukti-bukti yang cukup. Dalam kehidupan 
bermasyarakat kita pun demikian, Masyarakat lebih percaya pada berita-berita yang sulit dibuktikan kebenarannya.

"Babi itu harus dihabisi Pak Dukuh! (Jagal, p.6, hlmn.26).

Kata babi artinya binatang peliharaan masyarakat. Dalam situasi normal kata ini pun tidak memiliki makna tambahan atau makna kiasan. Dalam situasi emosi, kata babi maknanya sangat kasar, karena manusia yang sedang dimarahi disamakan seperti binatang babi. Sehingga, masyarakat desa Pedukuhan Gading meminta kepada Pak Dukuh agar babi (Karto) harus dihabisi atau ditiadakan, mungkin dengan cara membunuhnya atau dengan cara lain. Asal cara dihabisi yang ditempuh Pak Dukuh agar Karto tidak ada atau hidup lagi.

Harus dibabat biar jadi tape, "kata salah seorang pengikut Dukuh Sukat. (Jagal, p.6, hlmn.26).

Kalimat pada data tersebut menunjukkan bahwa kekerasan verbal terdapat pada kata dibabat dan biar jadi tape. Dibabat secara leksikal artinya ditebas atau dipotong. Biar jadi tape itu berarti menyerupai tape (tapai) atau seperti penganan, kue yang terbuat dari tepung beras atau singkong. Apakah seorang dapat dipenganan seperti tape (tapai)? Ini semua akbiat ekspresi masyarakat desa Pedukuhan Gading yang sudah sangat resah dan emosional dengan ulah Karto yang selalu meresahkan warga. Data kekerasan verbal pada data 6 di atas juga hampir sama dengan data di bawah ini.

Salah satu cara untuk menghabisi 'penyakit' itu hanya dengan membabat kirik Karto, Pak Sukat, "teriak yang lain (Jagal, p.7, halmn.27).

Karto dianggap sebagai penyakit sosial. Oleh karena itu, hampir semua warga desa Pedukuhan Gading bersepakat untuk membabat kirik Karto. Kirik artinya merasa takut, ngeri (KBBI, 2008: 729). Ini menunjukkan warga telah merasa takut, dan selalu merasakan kengerian akibat perbuatan Karto yang selalu membunuh, merampok, dan memperkosa.

Satu dua pukulan, tiga empat tendangan (Jagal, p.8, hlmn.27).

Luapan kemarahan dan kengerian yang dialami oleh masyarakat desa Pedukuhan Gading seperti digambarkan pada data di atas terekspresikan melalui pukulan dan tendangan beramai-ramai oleh warga. Dapatlah dibayangkan kalau semua warga memukul sampai satu sampai dua pukulan dan tiga sampai empat tendangan, maka Karto akan benar-benar menjadi tape (tapai) seperti digambarkan pada data 6 di atas. 
Walaupun dihalau oleh sebagian warga yang tidak menyetujui tindakan main hakim sendiri warga, namun sesekali tinju atau tendangan para penduduk itu bisa juga menerobos ke muka dan perut Karto. Gambaran kemarahan warga menghajar Karto walau dihadang sebagian warga tersebut tampak pada data di bawah ini.

Sesekali tinju atau tendangan para penduduk itu bisa juga menerobos ke muka dan perut Karto (Jagal, p.9, hlmn. 27).

Berusaha untuk menghajar Karto di antara hadangan banyak orang benar-benar mencerminkan emosional warga yang tak terbendung.

Karto yang sudah babak belur dihajar warga desa (Jagal, p.9, hlmn. 27).

Karto akhirnya menjadi tidak seperti Karto dahulu yang tegar, kekar, dan berani. Dia telah menjadi korban kemarahan warga dan seketika telah berubah tak punya bentuk selesai babak belur dihajar warga. Ibarat penghakiman terakhir, warga berteriak kepada Pak Dukuh, kepala Suku untuk tidak mengampuni Karto. Mereka terus berteriak mendesak Pak Dukuh untuk segera memberikan hukuman yang pas dengan perbuatan yang telah dilakukan oleh Karto. Salah satu teriakan para warga adalah seperti data di bawah ini.

Dosanya sudah terlalu besar Pak!" (Jagal, p.13, hlmn 27).

Dosanya sudah terlalu besar. Ini menggambarkan bahwa perbuatan Karto tidak bisa diampuni lagi. Jalan keluar satu-satunya yang bisa diambil adalah membabat atau membunuh Karto agar warga desa Pedukuhan Gading bisa hidup lebih tenang dan aman.

Tangan kanan membawa golok yang masih dibasahi darah (Jagal, p.25, hlmn.28).

Data yang tercetak tebal di atas, golok yang masih dibasahi darah, menunjukkan bahwa ada sebilah golok atau parang yang baru saja digunakan untuk menggorok leher seorang yang bernama Warsinah. Golok tersebut masih penuh darah, dan mengalir memenuhi mata golok yang sedang dipegang oleh Karto. Bagi siapa saja yang melihat langsung golok yang masih dibasahi darah pasti akan merasa ngeri dan menakutkan. Mungkin orang tersebut akan lari dan bersembunyi. Pada saat itu, sesungguhnya golok yang masih dibasahi darah dipandang sebagai suatu kekerasan verbal. Dari golok yang masih dibasahi darah tersebut hendak menyatakan kepada orang lain bahwa segera meninggalkan tempat itu, atau jangan "macam-macam" kalau tidak maka orang itu akan menjadi korban berikutnya.

Sekarang saya siap dikrangkeng (Jagal, p.28, hlmn.28) 
Data kekerasan verbal terdapat pada kata dikrangkeng. Kata ini berarti kurungan atau bilik berterali yang disiapkan sebagai tempat bagi para hukuman. Ketika Karto puas melakukan kekerasan, maka dia pun bersedia dikrangkeng. Artinya, dia bersedia menerima hukuman atas seluruh perbuatannya yang telah dilakukan kepada orang lain. Dikrangkeng, artinya membuat tidak bergerak bebas. Bahkan, Karto ibarat seekor binatang yang siap dikandangkan. Kata yang sama juga ditemukan pada kalimat "Bukan untuk mengkrangkengmu (Jagal, p.21, hlmn.27)". Data menunjukkan sekaligus menandakan ketakberdayaan seorang Karto untuk dikrangkeng, namun dalam kalimat yang lain menunjukkan seakan-akan Karto tidak bersalah dan tidak akan dikrangkeng.

\section{PENUTUP}

Berdasarkan uraian di atas, disimpulkan bahwa kekerasan verbal musti dihindari dalam interaksi sosial. Jika tidak, maka akan menimbulkan konflik di antara sesama. Jika itu yang terjadi, dapat dipastikan bahwa relasi kemesraan yang telah lama dibangun di antara komponen masyarakat tinggal kenangan. Di titik inilah, kehidupan kita akan dipenuhi dengan dendam dan kekerasan.

\section{DAFTAR PUSTAKA}

Barker, Chris. 2004. Cultural Studies. Teori \& Praktik. Penerjemah: Nurhadi.

Yogyakarta: Kreasi Wacana.

Baryadi, Praptomo I. 2012. Bahasa, Kekuasaan, dan Kekerasan. Yogyakarta: Universitas Sanata Dharma.

Miles dan Huberman. 2009. Analisis Data Kualitatif. Terjemahan oleh Tjetjep Rohendi

Rohidi. Jakarta: UI-PRESS.

Rampan, Korrie Layun. 1995. Aliran-aliran Jenis Cerita Pendek. Ende: Nusa Indah.

Taum, Yoseph Yapi. 1997. Pengantar Teori Sastra. Ende: Nusa Indah. 